25(6), 977-985

\title{
Testing and Adjustment for Inhomogeneity Temperature Series Using the SNHT Method
}

\author{
Yung-Seop Lee ${ }^{1} \cdot$ Hee-Kyung Kim ${ }^{2} \cdot$ Jung-In Lee ${ }^{3} \cdot$ Jae-Won Lee $^{4} \cdot$ Hee-Soo Kim $^{5}$ \\ ${ }^{1}$ Department of Statistics, Dongguk University; ${ }^{2}$ Department of Statistics, Dongguk University \\ ${ }^{3}$ Department of Statistics, Dongguk University; ${ }^{4}$ KMA Meteorological Resources Division \\ ${ }^{5}$ KMA Meteorological Resources Division
}

(Received November 6, 2012; Revised December 4, 2012; Accepted December 5, 2012)

\begin{abstract}
Data quality and climate forecasting performance deteriorates because of long climate data contaminated by non-climatic factors such as the station relocation or new instrument replacement. For a trusted climate forecast, it is necessary to implement data quality control and test inhomogeneous data. Before the inhomogeneity test, a reference series was created by $d$ index to measure the temperature series relationship between the candidate and surrounding stations. In this study, a inhomogeneity test to each season and climatological station was performed on the daily mean temperatures, daily minimum temperatures and daily maximum temperatures. After comparing two inhomogeneity tests, the traditional and the adjusted SNHT method, we found the adjusted SNHT method was slightly superior to the traditional one.
\end{abstract}

Keywords: Inhomogeneity test, $d$ index, data quality control, SNHT method.

\section{1. 서론}

기후자료의 균질성 검증과 균질화를 통한 보정된 기후자료 생산은 세계 여러 국가에서 이루어져서 기후 변화 연구에 활용되고 있다. 미국과 캐나다와 같은 선진국에서는 기후예측값을 산출할 때 자료품질관 리와 보정에 대한 작업을 권장하고 있다. 하지만 우리나라에서는 이에 대한 연구가 매우 부족한 실정이 다. 장기간의 기후자료들은 예측 불가능한 비기후적 요인들에 의해서 영향을 받아 품질이 저하되고 기 후예측의 결과 또한 신뢰할 수 없게 되는 경우가 있다. 기후자료를 오염시키는 비기후적 요인들에는 도 시화로 인한 관측지점이나 장비의 이동, 새로운 관측장비의 사용, 관측방법이나 기록방법의 변경, 관측 시간의 변동 및 관측 주변 환경의 변화 등의 인위적인 요인들이 있다. 이러한 인위적인 요인들을 제거 하고 기후에 의한 변화만을 반영하는 기후자료를 위해서는 관측자료에 대한 품질관리가 우선되어야 하 며 자료의 비균질성(inhomogeneity)에 대한 검증이 필요하다. 해외에서는 다양한 기법들을 비교분석 하면서 기후자료의 균질성 문제를 오랫동안 연구하였으며 현재에도 활발히 진행되고 있다 (Reeves 등, 2007). 국내에서는 기후자료의 균질성에 관하여 문제제기에 그쳤으며 실제로 다양한 기법들을 기상자

This work was funded by the Korea Meteorological Administration Research and Development Program under Grant CATER 2012-3120.

${ }^{1}$ Corresponding author: Professor, Department of Statistics, Dongguk University -Seoul, Seoul 100-715, Korea. E-mail: yung@dongguk.edu 
료에 적용하여 분석한 경우는 드물다. 최근에야 기상자료가 방대해지고 복잡해짐에 따라 중요한 이슈로 등장하고 있는 실정이다. 기상청에서 관측지점의 이전에 따라 발생할 수 있는 기상청 기후자료의 균질 성 문제와 (Ryoo 등, 2006), 통계지침의 변경에 따른 기후자료의 균질성 문제를 다룬바 있다 (Ryoo와 $\mathrm{Kim}, 2007$ ). 또한, Kim 등 (2004)에서는 MASH(Multiple Analysis of Series for Homogenization) 방 법을 사용하여 81 년간의 기온자료에 대한 균질성 검정을 실시하였고, Kim과 Suh (2008)에서는 우리나 라의 최근 강수 변화 시점(change-point)을 찾는 연구가 이루어졌다. 본 연구에서는 Alexandersson과 Moberg (1997)가 제안한 SNHT(Standard Normal Homogeneity Test) 방법과 이 방법의 절차 중 일 부를 수정한 SNHT 방법을 이용하여 우리나라 기상관서별 기온자료에 대해 비균질성 검정을 실시한다. 또한 원래의 SNHT와 수정한 SNHT 방법을 비교분석하고, 비균질한 자료에 대해서는 적절한 보정을 실시하여 관측자료의 균질성을 확보하고자 한다.

\section{2. 연구 방법}

자료의 비균질성 검정에서 검정하고자 하는 대상지점(candidate station)의 시간에 따른 연속적인 기 후자료를 대상시계열(후보시계열, candidate series)이라 한다. 이에 대한 비균질성 검정은 주변지 점(surrounding stations) 자료와의 비교를 통해 이루어지게 되는데 이때 대상시계열과 관련성이 높은 주변지점의 연속적인 기후자료를 기준시계열(reference series)이라 한다. 본 연구에서는 이러한 기후자 료 중 1981년 2011년 기온자료의 일평균기온, 일최저기온, 일최고기온 자료를 계절별로 나누어 각각 의 계절별 연평균 기온을 산출하여 비균질성 검정을 실시하였다. 계절구분은 현재 기상청에서 사용하고 있는 기준을 따랐는데, 3 월 5 월은 봄, 6 월 8 월은 여름, 9 월 11 월은 가을, 12 월부터 이듬해 2 월까지 를 겨울로 구분하였다. 또한 우리나라 79 개 기상관서 중 춘천, 강릉, 서울, 인천, 대전, 포항, 부산, 목 포, 여수, 제주도, 울릉도의 11 개 지점이 $\mathrm{WMO}$ 에 등록되어 있다. $\mathrm{WMO}$ 에 등록되어 있는 11 개 지점 과 그 외의 68 개 기상관서들을 구분하기 위해 편의상 등록된 관서들을 기후관측소라 명명하겠다. 본 연 구에서는 춘천, 서울, 대전, 포항, 목포의 5 개 기후관측소의 기온자료에 대해 비균질성 검정을 실시하였 다. Durre 등 (2010)에서는 대상지점을 중심으로 $75 \mathrm{~km}$ 이내의 주변지점 중 기온자료와 상관성이 높은 3 개 7개 지점을 선정하기 위한 측도로써 Legates와 McCabe Jr. (1999)가 제시한 $d$ index를 이용하였 다. 본 연구에서도 이와 비슷하게 각 계절별로 검정대상 지점과의 거리가 반경 $70 \mathrm{~km}$ 이내인 주변지점 중 $d$ index 값이 가장 높은 3 개 지점의 기온자료를 기준시계열로 선택하였다. Legates와 McCabe Jr. (1999) 가 제시한 $d$ index는 식 (2.1)과 같다.

$$
d=1.0-\frac{\sum_{i=1}^{m}\left|X_{i}-Y_{i}\right|}{\sum_{i=1}^{m}\left[\left|Y_{i}-\bar{X}\right|+\left|X_{i}-\bar{X}\right|\right]},
$$

여기서 $Y_{i}$ 는 대상시계열이고 $X_{i}$ 는 기준시계열, $\bar{X}$ 는 기준시계열의 평균이다. 또한 $m$ 은 관측치 수를 의미한다. 선택된 기준시계열 기온자료를 이용하여 전통적인 방법인 SNHT 방법 (Alexandersson와 Moberg, 1997)을 적용하여 검정을 실시하였다. 이 SNHT 기법은 대상지점의 시계열 기온자료와 주변 지점들의 시계열 기온자료를 이용하여 식 $(2.2)$ 와 같은 $Q$-시계열을 생성한다.

$$
Q_{i}=Y_{i}-\left[\sum_{j=1}^{k} r_{j}^{2} X_{j i}-\bar{X}_{j}+\bar{Y}\right] / \sum_{j=1}^{k} r_{j}^{2},
$$

여기서 $Y_{i}$ 는 $i$ 년도 대상시계열의 기온자료값을 나타낸다. $X_{j}$ 는 $j$ 개의 주변지점 시계열 기온자료 중 $j$ 번째 주변지점의 기준시계열 기온자료를 의미하고, $X_{j i}$ 는 $j$ 번째 주변지점의 기준시계열에서 $i$ 년도 기 
온자료값을 나타낸다. $\bar{Y}$ 는 대상시계열 기온자료의 평균값, $\bar{X}_{j}$ 는 $j$ 번째 주변지점의 기준시계열 기온 자료의 평균값이며, $r_{j}$ 는 대상시계열 기온자료와 $j$ 번째 기준시계열 기온자료의 상관계수를 나타낸다. $Q$-시계열을 식 $(2.3)$ 과 같이 표준화하여 $Z$-시계열을 정의한다.

$$
Z_{i}=\frac{\left(Q_{i}-\bar{Q}\right)}{\sigma_{Q}}
$$

여기서 $\bar{Q}$ 와 $\sigma_{Q}$ 는 각각 $Q$-시계열의 평균과 표준편차를 나타낸다.

대상시계열 기온자료 $Y$ 에 대한 비균질성 검정시 귀무가설과 대립가설은 식 (2.4)와 같이 식 (2.3)의 $Z$-시계열을 이용하여 표현할 수 있다.

$$
H_{0}: Z_{i} \in N(0,1), \quad i \in\{1, \ldots, n\} \quad \text { vs. } H_{1}: \begin{cases}Z_{i} \in N\left(\mu_{1}, \sigma\right), & i \in\{1, \ldots, a\}, \\ Z_{i} \in N\left(\mu_{2}, \sigma\right), & i \in\{a+1, \ldots, n\},\end{cases}
$$

여기서 $n$ 은 전체 관측치 수를 나타낸다. 귀무가설은 식 (2.3)의 표준화된 $Z$-시계열이 표준정규분포를 따르는 것으로 대상시계열 기온자료가 균질하는 것을 의미한다. 대립가설은 귀무가설에서의 기간을 두 부분으로 나누어 $\{1, \ldots, a\}$ 시점의 $Z$-시계열 평균 $\mu_{1}$ 과 $\{a+1, \ldots, n\}$ 시점의 $Z$-시계열 평균 $\mu_{2}$ 로 나 타내어 대상시계열 기온자료의 $a+1$ 시점에서 평균의 변화가 생겨 자료의 오염이 발생했다는 것으로 설정한다. 즉 대립가설은 대상시계열 기온자료가 비균질하다는 것을 의미한다. 이때 계산의 편의상 대 립가설에서는 등분산을 가정한다.

식 (2.4)의 귀무가설과 대립가설을 이용하여 우도비(likelihood ratio)를 유도하면 식 (2.5)와 같다.

$$
L=\frac{\text { Likelihood }\left.\right|_{H_{1}}}{\text { Likelihood }\left.\right|_{H_{0}}}=\frac{(2 \pi)^{-\frac{n}{2}}}{\sigma^{n}} \exp \left\{-\frac{1}{2 \sigma^{2}}\left(\sum_{i=1}^{a}\left(z_{i}-\mu_{1}\right)^{2}+\sum_{i=a+1}^{n}\left(z_{i}-\mu_{2}\right)^{2}\right)+\frac{1}{2} \sum_{u=1}^{n} z_{i}^{2}\right\} .
$$

식 (2.5)에서 모수들을 MLE로 대체하여 식 (2.6)과 같이 검정통계량을 유도할 수 있다. 유도과정에 대 한 자세한 과정은 Alexandersson과 Moberg (1997)의 부록에 나와 있다.

$$
T_{\max }=\max _{1 \leq a \leq n-1}\left\{T_{a}\right\}=\max _{1 \leq a \leq n-1}\left\{a \bar{z}_{1}^{2}+(n-a) \bar{z}_{2}^{2}\right\},
$$

여기서 $\bar{z}_{1}$ 과 $\bar{z}_{2}$ 는 각각 $\{1, \ldots, a\}$ 시점의 $Z$-시계열과 $\{a+1, \ldots, n\}$ 시점의 $Z$-시계열의 평균을 나타낸 다. 모든 가능한 시점 $a$ 에 대해 $a \bar{z}_{1}^{2}+(n-a) \bar{z}_{2}^{2}$ 값들을 계산하고 이때 가장 큰 값을 $T_{\max }$ 라 한다. 식 (2.6)에 나타나있는 검정통계량값 $T_{\max }$ 를 Alexandersson과 Moberg (1997)가 제시한 임계값(critical value)과 비교하여 귀무가설의 기각여부를 결정한다. 만약 계산된 검정통계량값이 임계값보다 크면 대 상시계열 기온자료가 균질하다는 귀무가설을 기각한다. 귀무가설이 기각된 $T_{\max }$ 를 갖는 시점 $a$ 이후에 서부터 기온자료 평균의 급격한 변화가 발생하여 자료가 인위적인 요인에 의해 오염되었을 것이라 추정 한다. 대립가설에서 두 번째 시계열자료 $Z_{i} \in N\left(\mu_{2}, \sigma\right), i \in\{a+1, \ldots, n\}$ 의 시작시점, 즉 기온자료 평 균의 변화가 발생하기 시작하는 $a+1$ 시점을 불연속점(break point)이라 한다. 대상시계열 기온자료에 서 처음 찾아진 불연속점을 기준으로 전 시점과 후 시점의 자료들 각각에 대해서 다시 비균질성 검정을 실시한다. 이 과정을 더 이상 유의한 불연속점이 나오지 않을 때까지 반복 실시함으로써 대상시계열 기 온자료에 존재하는 여러 개의 유의한 불연속점을 모두 찾아낼 수 있다.

자료가 비균질한 것으로 판단되면 자료의 균질성 확보를 위해 적합한 보정이 이루어져야 한다. 자료의 보정은 대상시계열 기온자료 중 불연속점 이전인 $\{1, \ldots, a\}$ 시점의 자료에 대해서 $\bar{q}_{2}-\bar{q}_{1}$ 을 더해준다. 여기서 $\bar{q}_{1}$ 과 $\bar{q}_{2}$ 는 각각 불연속점 이전 시점 $\{1, \ldots, a\}$ 과 이후 시점 $\{a+1, \ldots, n\}$ 의 $Q$-시계열의 평균 을 의미한다. 
SNHT 방법에서 사용하는 식 (2.2)의 $Q$-시계열은 대상시계열 기온자료와 기준시계열 가중평균과의 차 이이다. 가중평균에서의 가중치는 각 기준시계열 기온자료와 대상시계열 기온자료와의 상관계수를 제 곱한 값이다. 즉, 대상지점의 실제 기후와 관련성이 높은 기준시계열 기온자료에는 큰 가중치가 부여되 고, 상대적으로 관련성이 낮은 기준시계열 기온자료에는 작은 가중치가 부여된다. 한편, 식 (2.2)의 $Q$ 시계열은 기준시계열들이 균질하다고 가정하고 있다. 그러나 실제로 대상지점 기온의 변동성을 포함하 고 있으면서 자료오염이 발생하지 않은 균질한 기준시계열 기온자료를 생산하는 일은 쉽지 않다. 균질 한 기준 시계열 생성을 위하여 Peterson과 Easterling (1994)은 주변지점들의 기준시계열들을 1 차 차분 한 후 최대값과 최소값을 제외하고 산술평균함으로써 하나의 균질한 기준시계열을 생성하였다. 본 연구 에서는 차분한 기준시계열을 산술평균하지 않고 Young (1994)이 제시한 식 (2.7)의 $w_{j}$ 를 가중치로 한 가중평균을 사용하여 새로운 기준시계열 기온자료 $T^{*}$ 를 생성하였다.

$$
w_{j}=\frac{r_{j}^{2}\left(n_{j}-2\right)}{1-r_{j}^{2}}, \quad j=1,2, \ldots, k,
$$

여기서 $r_{j}$ 는 Peterson과 Easterling (1994)이 제시한 방법에 따라 1차 차분(differencing)한 대상시계 열 기온자료와 1 차 차분한 기준시계열 기온자료의 상관계수이며, $n_{j}$ 는 관측치 수를 나타낸다. 실제로 $w_{j}$ 는 상관계수의 유의성을 검정하는 $t$-통계량의 제곱형태로써, $w_{j}$ 값이 클수록 상관관계의 유의성이 크 다는 것을 의미하며 더 많은 가중치를 평균에 반영한다.

\section{3. 연구결과}

원래의 SNHT 방법을 그대로 적용하는 경우와 Peterson과 Easterling (1994)이 제시한 방법을 수정하 여 새로운 기준시계열 기온자료 $T^{*}$ 를 만든 후 $\mathrm{SNHT}$ 방법을 적용한 경우 각각에 대해 비교해보았다. 편의상 새로운 기준시계열 기온자료 $T^{*}$ 를 만든 후에 적용한 SNHT 방법을 수정된(adjusted) SNHT 방 법이라 하겠다. 원래의 SNHT 방법과 수정된 SNHT 방법으로 5 개 기후관측소의 일평균기온, 일최저 기온, 일최대기온 자료에 대한 계절별 비균질성 검정 결과는 Table 3.1 에 나타나있다. 검정결과 자료가 균질한 것으로 나타나 추후 자료의 균질성 확보를 위한 보정이 필요하지 않는 경우는 ' $\mathrm{H}$ '로, 비균질한 것으로 나타난 경우는 불연속점에 해당하는 연도를 표시하였다. 예를 들어 춘천지역의 봄 연평균기온에 대한 비균질성 검정결과 SNHT 방법에 의해서는 1996 년에 가장 유의한 자료의 오염이 발생하였고, 이 시점을 기준으로 전과 후의 자료들에 대해 각각 다시 비균질성 검정을 실시한 결과 2007 년에도 자료의 오염이 발생한 것으로 나타났다. 수정된 SNHT 방법에 의해서는 1994년에 가장 유의한 자료의 오염이 발생하였고, 다음으로 2006 년에도 자료의 오염이 발생한 것으로 나타났다. 원래의 SNHT 방법과 수정 된 SNHT 방법을 적용한 결과를 비교해보면 각 기후요소에서 자료오염 발생시점으로 찾은 불연속점의 연도가 다른 것을 알 수 있다. 특히 한 시점(1년)의 차이를 보이는 경우가 많은 것을 알 수 있다. 좀 더 구체적인 차이점을 보기 위해 SNHT 방법에서 사용하는 기준시계열 기온자료(대상시계열 기온자료와 의 상관계수 제곱으로 가중평균하여 만든 값)와 수정된 SNHT 방법에서 사용하는 기준시계열 기온자료 (Peterson과 Easterling (1994)이 제시한 방법을 수정하여 만든 새로운 기준시계열 기온자료값)를 대상 시계열 기온자료와 함께 나타내보았다.

Figure 3.1은 춘천지역의 봄 연평균기온 시계열이다. Figure 3.1에서 S로 표시된 시점은 SNHT 방법에 의해 찾아진 불연속점이고 Sadj로 표시된 시점은 수정된 SNHT 방법에 의해 찾아진 불연속점이다. 불 연속점은 기준시계열 기온자료와 비교하여 대상시계열 기온자료의 패턴이 달라지는 시점으로, 해당 시 점에서 자료의 오염이 발생되었다고 볼 수 있다. 두 방법에 의해 찾아진 불연속점이 차이를 보이는 것 을 알 수 있다. 구체적으로 살펴보기 위해 대상시계열과 각 방법에 의한 기준시계열의 차이값을 Figure 
Table 3.1. Inhomogeneity test results(break point years) by the traditional SNHT and the adjusted SNHT methods

\begin{tabular}{|c|c|c|c|c|c|c|c|}
\hline \multirow[b]{3}{*}{ Station } & \multirow[b]{3}{*}{ Season } & \multicolumn{6}{|c|}{ Correction durations(correction factors) for seasonal mean of } \\
\hline & & \multicolumn{2}{|c|}{$\begin{array}{l}\text { daily mean } \\
\text { temperatures }\end{array}$} & \multicolumn{2}{|c|}{$\begin{array}{c}\text { daily minimum } \\
\text { temperatures }\end{array}$} & \multicolumn{2}{|c|}{$\begin{array}{c}\text { daily maximum } \\
\text { temperatures }\end{array}$} \\
\hline & & SNHT & $\begin{array}{l}\text { Adjusted } \\
\text { SNHT }\end{array}$ & SNHT & $\begin{array}{c}\text { Adjusted } \\
\text { SNHT }\end{array}$ & SNHT & $\begin{array}{c}\text { Adjusted } \\
\text { SNHT }\end{array}$ \\
\hline \multirow{8}{*}{$\begin{array}{c}\text { Chuncheon } \\
\text { (101) }\end{array}$} & \multirow{2}{*}{ Spring } & 1996 & 1994 & 2000 & 1995 & 2007 & 2006 \\
\hline & & 2007 & 2006 & & 1986 & & \\
\hline & \multirow{2}{*}{ Summer } & 2007 & 2006 & 1996 & 1995 & 2007 & 2006 \\
\hline & & & & 1984 & & 2000 & 1999 \\
\hline & \multirow{2}{*}{ Autumn } & 1995 & 1994 & 1999 & 1998 & \multirow{2}{*}{$\mathrm{H}$} & 2008 \\
\hline & & 2006 & 2005 & & 1985 & & \\
\hline & \multirow{2}{*}{ Winter } & 1997 & 1996 & 1999 & 1996 & \multirow{2}{*}{$\mathrm{H}$} & \multirow{2}{*}{$\mathrm{H}$} \\
\hline & & & 1985 & & & & \\
\hline \multirow{5}{*}{$\begin{array}{l}\text { Seoul } \\
(108)\end{array}$} & Spring & 2006 & 2005 & 2007 & 2006 & 2006 & 2005 \\
\hline & Summer & 2006 & $\mathrm{H}$ & $\mathrm{H}$ & $\mathrm{H}$ & 2010 & $\mathrm{H}$ \\
\hline & Autumn & 2007 & 2006 & 2007 & 2006 & 1996 & 2003 \\
\hline & Wrinto & 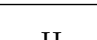 & 2004 & 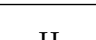 & 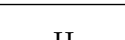 & 2005 & 2004 \\
\hline & Winter & $\mathrm{H}$ & 2004 & H & $\mathrm{H}$ & & 1999 \\
\hline \multirow{7}{*}{$\begin{array}{c}\text { Daejeon } \\
(133)\end{array}$} & \multirow{2}{*}{ Spring } & \multirow[t]{2}{*}{2006} & \multirow[t]{2}{*}{1998} & \multirow{2}{*}{$\mathrm{H}$} & \multirow{2}{*}{$\mathrm{H}$} & 2006 & 2005 \\
\hline & & & & & & & 2000 \\
\hline & \multirow{2}{*}{ Summer } & 2007 & 1996 & 2007 & 1996 & 2006 & 2005 \\
\hline & & 1997 & & & & & \\
\hline & \multirow{2}{*}{ Autumn } & 1997 & 1996 & \multirow{2}{*}{$\mathrm{H}$} & \multirow{2}{*}{$\mathrm{H}$} & \multirow[t]{2}{*}{2005} & 2004 \\
\hline & & & 1987 & & & & \\
\hline & Winter & $\mathrm{H}$ & $\mathrm{H}$ & $\mathrm{H}$ & $\mathrm{H}$ & 2005 & 2004 \\
\hline & Snring & 1988 & $\mathrm{H}$ & 1987 & 1986 & $\mathrm{H}$ & $H$ \\
\hline & spring & 2003 & $\Pi$ & 2003 & 2002 & $\Pi$ & 11 \\
\hline Pohang & Summer & 1988 & 1987 & 1989 & 1988 & $\mathrm{H}$ & $\mathrm{H}$ \\
\hline (138) & A & 1988 & 1986 & 1987 & 1984 & 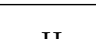 & 1986 \\
\hline & Autumn & & & 1996 & & $\Pi$ & \\
\hline & Winter & $\mathrm{H}$ & $\mathrm{H}$ & 1988 & $\mathrm{H}$ & $\mathrm{H}$ & $\mathrm{H}$ \\
\hline & & 2010 & 2009 & & & 1999 & 1998 \\
\hline & Spring & & & $\mathrm{H}$ & $\mathrm{H}$ & & 1989 \\
\hline & & & & & & & 2009 \\
\hline & C. & 2010 & 2009 & 2010 & 2009 & 2009 & 2008 \\
\hline 1VIOKро & summer & & 1992 & & 2000 & & \\
\hline & $\Delta$ & 2010 & 2009 & 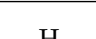 & $\mathrm{H}$ & 1999 & 1998 \\
\hline & Autumn & & & H & $H$ & & 2009 \\
\hline & Winter & $\mathrm{H}$ & 2002 & $\mathrm{H}$ & $\mathrm{H}$ & 1998 & 1997 \\
\hline & DVImLer & 11 & & 11 & 11 & & 1990 \\
\hline
\end{tabular}

3.2 에 나타내었다. 수평선으로 표시된 부분은 각 방법에서 탐색한 불연속점을 기준으로 나누어진 각각 의 시계열의 평균값을 의미한다. Figure 3.2 의 대상시계열과 기준시계열의 차이값을 살펴보면 수정된 SNHT 적용의 경우 차이값이 일정 수준을 유지하다가 급격하게 떨어지는 시점인 1994년과 2006년을 불연속점으로 탐색한 것을 알 수 있다. 반면 SNHT 방법을 적용한 경우 차이값이 일정 수준을 유지하 다가 급격하게 떨어지는 시점이 아닌 그 이후 시점인 1996년과 2007년을 불연속점으로 탐색한 것을 알 


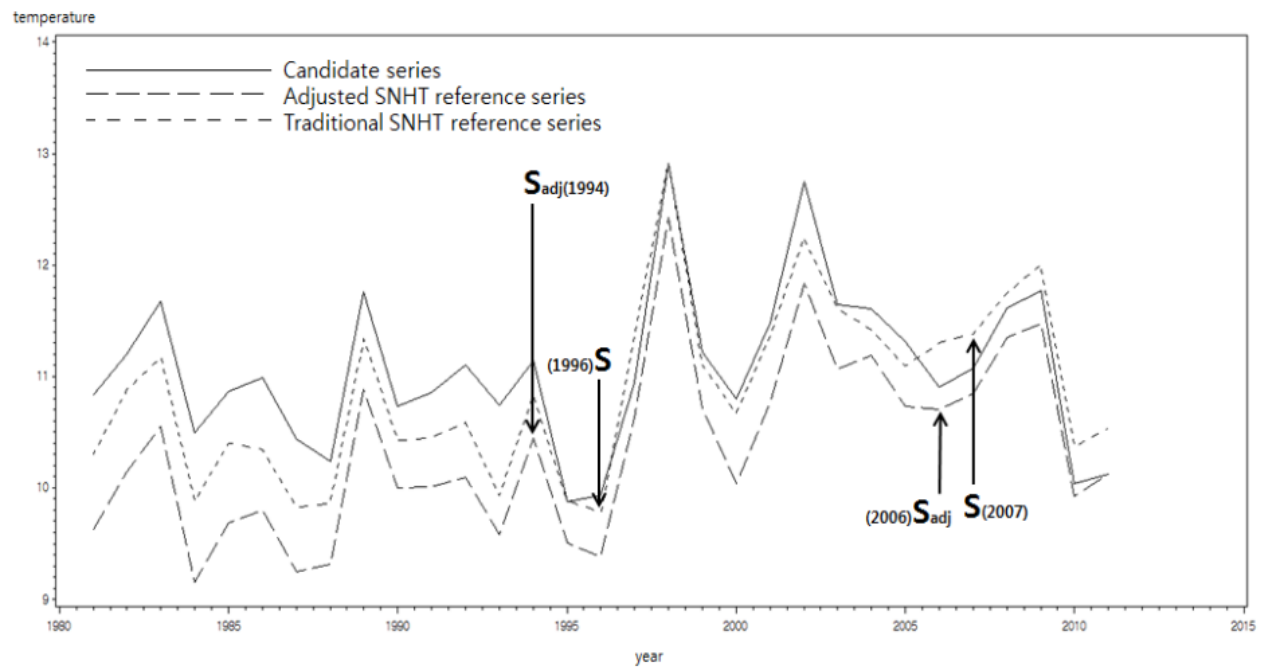

Figure 3.1. Candidate series, and reference series by the traditional SNHT and the adjusted SNHT method: Spring mean temperatures at Chuncheon

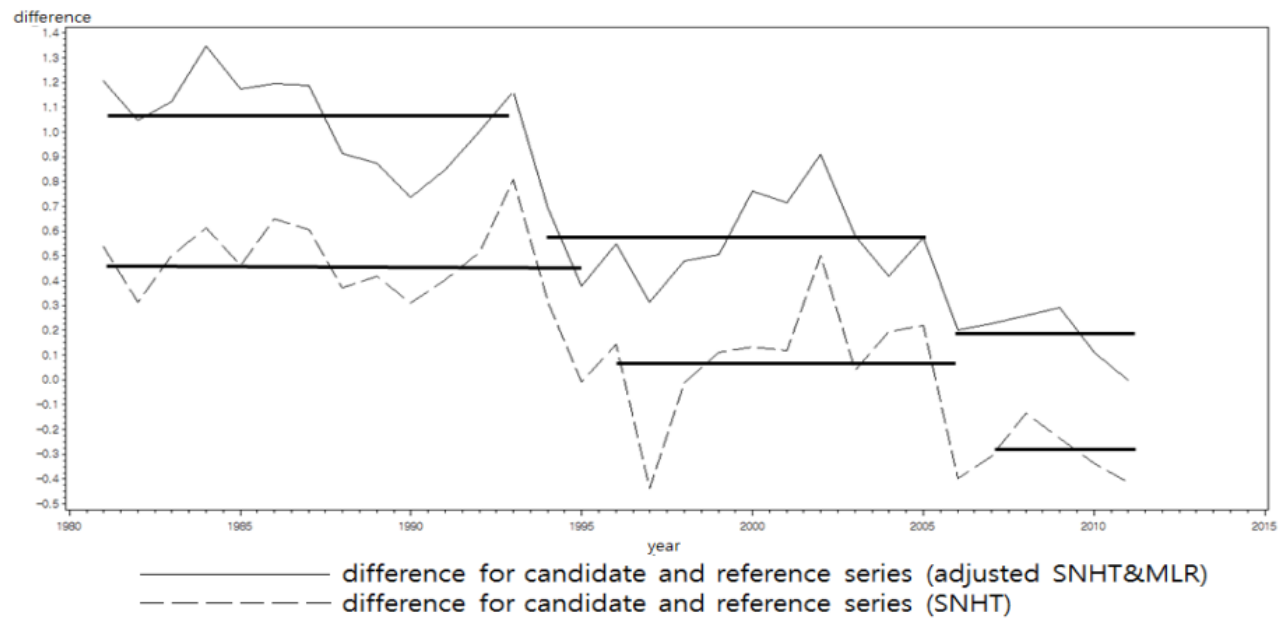

Figure 3.2. Differences for candidate and reference series by the adjusted SNHT and the traditional SNHT: Spring mean temperatures at Chuncheon

수 있다. 즉, 춘천지역의 봄 연평균기온 시계열 경우에는 수정된 SNHT 방법에 의한 결과가 대상시계열 기온자료와 기준시계열 기온자료의 패턴이 달라지는 시점과 일치한다고 볼 수 있으므로 수정된 SNHT 방법이 원래의 SNHT 방법보다 더 타당하다고 할 수 있다. 다른 지점 및 계절에 대해서도 동일한 방법 으로 확인해본 결과 대부분 수정된 SNHT 방법이 원래의 SNHT 방법보다 불연속점을 더 정확하게 탐 색하는 것으로 나타났다. 따라서 비균질한 자료에 대한 보정은 수정된 SNHT 방법의 적용결과를 바탕 으로 이루어졌다. 그 결과 각 경우의 보정기간과 보정계수(correction factor)가 Table 3.2에 나타나있 다. 보정계수는 앞에서 언급한 바와 같이 $\bar{q}_{2}-\bar{q}_{1}$ 값으로, $\bar{q}_{1}$ 과 $\bar{q}_{2}$ 는 각각 불연속점 이전 시점과 이후 시 점의 $Q$-시계열의 평균값이다. Table 3.2 의 수정된 SNHT 방법에 의한 보정계수를 이용하여 비균질성 
Table 3.2. Correction durations and factors by the adjusted SNHT

\begin{tabular}{|c|c|c|c|c|}
\hline \multirow[b]{2}{*}{ Station } & \multirow[b]{2}{*}{ Season } & \multicolumn{3}{|c|}{ Correction durations(correction factors) for seasonal mean of } \\
\hline & & $\begin{array}{l}\text { daily mean } \\
\text { temperatures }\end{array}$ & $\begin{array}{c}\text { daily minimum } \\
\text { temperatures }\end{array}$ & $\begin{array}{c}\text { daily maximum } \\
\text { temperatures }\end{array}$ \\
\hline \multirow{8}{*}{$\begin{array}{l}\text { Chuncheon } \\
\text { (101) }\end{array}$} & \multirow{2}{*}{ Spring } & $1981-1993(-0.6209)$ & $1981-1985(-1.0842)$ & $1981-2005(-0.5838)$ \\
\hline & & $1994-2005(-0.3910)$ & $1986-1994(-0.5459)$ & \\
\hline & \multirow{2}{*}{ Summer } & $1981-2005(-0.5129)$ & $1981-1994(-0.4653)$ & $1981-1998(-0.3247)$ \\
\hline & & & & $1999-2005(-0.8981)$ \\
\hline & \multirow{2}{*}{ Autumn } & $1981-1993(-0.6729)$ & $1981-1984(-1.1923)$ & $1981-2007(-0.4708)$ \\
\hline & & $1994-2004(-0.4109)$ & $1985-1997(-0.7451)$ & \\
\hline & \multirow{2}{*}{ Winter } & $1981-1984(-1.2994)$ & $1981-1995(-0.9980)$ & $\mathrm{H}$ \\
\hline & & $1985-1995(-0.6967)$ & & 11 \\
\hline \multirow{5}{*}{$\begin{array}{l}\text { Seoul } \\
(108)\end{array}$} & Spring & $1981-2004(-0.3742)$ & $1981-2005(-0.3974)$ & $1981-2004(-0.4640)$ \\
\hline & Summer & $\mathrm{H}$ & $\mathrm{H}$ & $\mathrm{H}$ \\
\hline & Autumn & $1981-2005(-0.2601)$ & $1981-2005(-0.3934)$ & $1981-2002(-0.2798)$ \\
\hline & \multirow{2}{*}{ Winter } & $1981-2003(-0.3732)$ & \multirow{2}{*}{$\mathrm{H}$} & $1981-1998(-0.2645)$ \\
\hline & & & & $1999-2003(-0.5678)$ \\
\hline \multirow{6}{*}{$\begin{array}{c}\text { Daejeon } \\
(133)\end{array}$} & \multirow{2}{*}{ Spring } & $1981-1997(-0.2767)$ & \multirow{2}{*}{$\mathrm{H}$} & $1981-1999(-0.5052)$ \\
\hline & & & & $2000-2004(-0.7540)$ \\
\hline & Summer & $1981-1995(-0.4731)$ & $1981-1995(-0.3477)$ & $1981-2004(-0.9022)$ \\
\hline & Autumn & $1981-1986(-0.1965)$ & $\mathrm{H}$ & $1981-2003(-0.4104)$ \\
\hline & คับ & $1987-1995(-0.4467)$ & & \\
\hline & Winter & $\mathrm{H}$ & $\mathrm{H}$ & $1981-2003(-0.2111)$ \\
\hline \multirow{5}{*}{$\begin{array}{c}\text { Pohang } \\
\text { (138) }\end{array}$} & \multirow{2}{*}{ Spring } & \multirow{2}{*}{$\mathrm{H}$} & $1981-1985(0.7074)$ & $\mathrm{H}$ \\
\hline & & & $1986-2001(-0.4483)$ & П \\
\hline & Summer & $1981-1986(0.5105)$ & $1981-1987(0.6231)$ & $\mathrm{H}$ \\
\hline & Autumn & $1981-1985(0.4317)$ & $1981-1983(0.8034)$ & $1981-1985(0.1800)$ \\
\hline & Winter & $\mathrm{H}$ & $\mathrm{H}$ & $\mathrm{H}$ \\
\hline \multirow{9}{*}{$\begin{array}{l}\text { Mokpo } \\
(165)\end{array}$} & \multirow{3}{*}{ Spring } & $1981-2008(-0.7142)$ & \multirow{3}{*}{$\mathrm{H}$} & $1989-1997(-1.4817)$ \\
\hline & & & & $1981-1988(-1.0432)$ \\
\hline & & & & $1998-2008(-0.8302)$ \\
\hline & \multirow{2}{*}{ Summer } & $1981-1991(-0.8229)$ & $1981-1999(-0.5875)$ & $1981-2007(-1.0790)$ \\
\hline & & $1992-2008(-1.1828)$ & $2000-2008(-0.9973)$ & \\
\hline & \multirow{2}{*}{ Autumn } & $1981-2008(-0.7328)$ & \multirow{2}{*}{$\mathrm{H}$} & $1981-1997(-1.4835)$ \\
\hline & & & & $1998-2008(-0.7229)$ \\
\hline & \multirow{2}{*}{ Winter } & $1981-2001(-0.3701)$ & \multirow{2}{*}{$\mathrm{H}$} & $1981-1989(-1.3415)$ \\
\hline & & & & $1990-1996(-2.0760)$ \\
\hline
\end{tabular}

에 대해 보정한 결과 중 춘천 지역 일평균기온의 계절별 연평균자료에 대한 보정결과가 Figure 3.3 에 나타나있다. 실선으로 표시한 시계열은 보정 전 기온자료이고 점선으로 표시한 시계열은 보정 후의 기 온자료를 나타낸다. 예를 들면, 봄의 경우 첫 번째 불연속점으로 탐색된 1994년 이전의 자료에 대해 서는 -0.6209 를 더해주고, 1994년부터 두 번째 불연속점으로 탐색된 2006년 이전의 자료에 대해서는 -0.3910 을 더해준 결과를 점선으로 나타낸 것이다. 보정 전 자료에 의하면 31 년 동안 춘천의 봄 평균 기온이 $0.3401^{\circ} \mathrm{C}$ 상승하였지만, 보정된 자료를 통해 보면 31 년 동안 봄 평균기온이 $1.0428^{\circ} \mathrm{C}$ 상승한 것 을 알 수 있다. 여름의 경우는 보정 전 자료에 의하면 $0.4669^{\circ} \mathrm{C}$ 상승한 것으로 나타났지만, 보정 후 자 료에 의해서는 $0.9477^{\circ} \mathrm{C}$ 상승한 것으로 나타났다. 가을과 겨울의 경우도 마찬가지로 각각 $1.2505^{\circ} \mathrm{C}$ 에서 

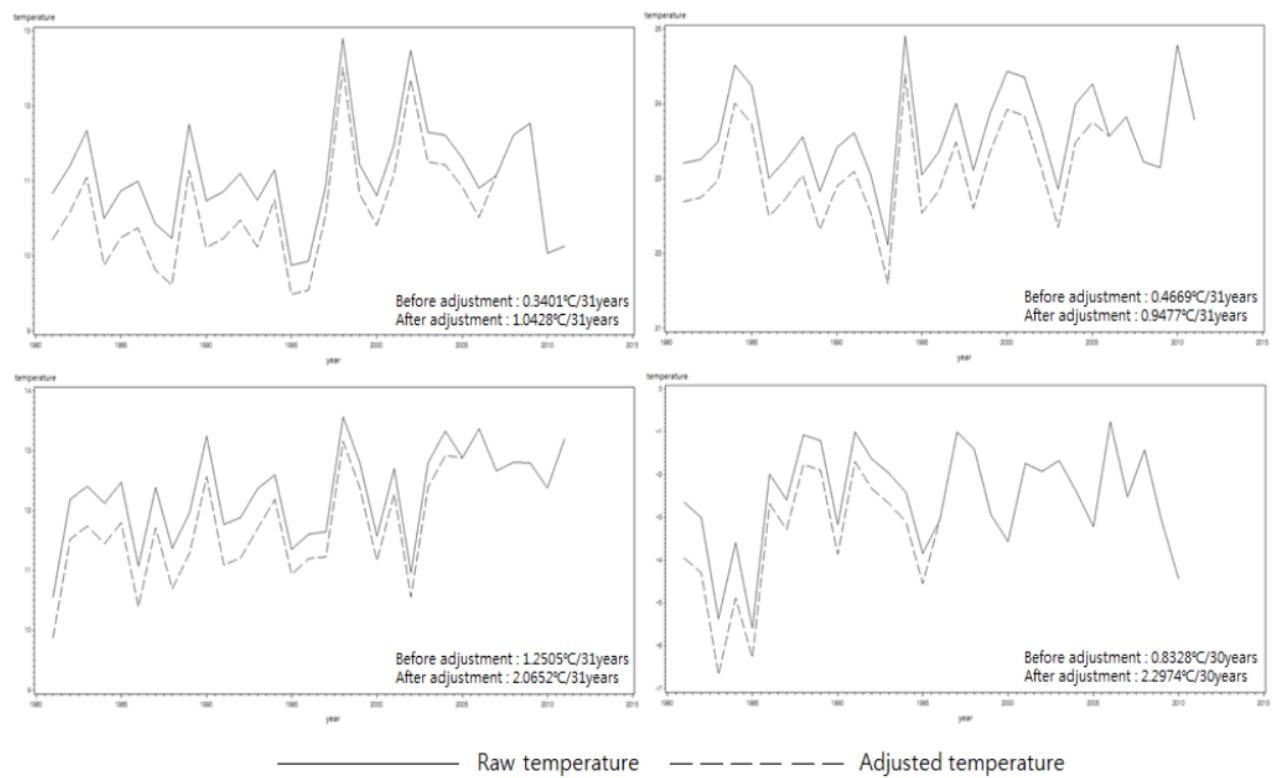

Figure 3.3. Seasonal mean temperatures before and after adjustment at Chuncheon(upper left: spring, upper right: summer, lower left: autumn, lower right: winter)

$2.0652^{\circ} \mathrm{C}$ 로, $0.8328^{\circ} \mathrm{C}$ 에서 $2.2974^{\circ} \mathrm{C}$ 로 31 년 동안 평균기온이 상승한 값이 달라지는 것을 알 수 있다. 보 정 후의 결과를 바탕으로 31 년 동안 봄, 여름에 비해 가을과 겨울의 온도가 크게 상승한 것을 알 수 있 다.

\section{4. 결론 및 향후과제}

본 연구에서는 봄, 여름, 가을, 겨울의 각 계절별로 일평균기온, 일최저기온, 일최고기온 자료에 대 해 SNHT 기법을 적용하여 비균질성을 검정하였다. 또한 기준시계열 생성시 Peterson과 Easterling (1994)이 제시한 방식을 수정한 '수정된 SNHT' 방법을 적용하여 비기후적 오염이 발생한 시점인 불연 속점을 찾고 자료의 비균질성을 비교 검정하였다. 그 결과 수정된 SNHT 방법이 더 타당한 것으로 판 단되었다. 이는 주어진 자료에서 각 방법의 기준시계열 기온자료와 대상시계열 기온자료의 비교를 통해 내린 결론이지만 향후 다른 검정방법을 적용해봄으로써 동일한 불연속점이 탐색되는지 여부에 대해 확 인해 볼 필요가 있다. 또한 검정 결과로 얻어진 불연속점에 대해서는 기상관서에 대한 이력 메타자료를 통해 실제로 관서이전이나 관측 장비교체와 같은 자료의 비기후적 오염요인이 발생했는지에 대해 논의 해 볼 필요가 있다. 그리고 춘천, 서울, 대전, 포항, 목포의 5 개 기후관측소의 기온자료에 대해 균질성 검정을 실시하였는데 향후 다른 기후관측소나 기온자료 외에 강수량과 같은 기후 요소들에 대해서도 확 대 적용해 보고자 한다.

\section{References}

Alexandersson, H. and Moberg, A. (1997). Homogenization of Swedish temperature data. part I : Homogeneity test for linear trends, Journal of Climatology, 17, 25-34. 
Durre, I., Menne, M. J., Gleason, B. E., Houston, T. G. and Vose, R. S. (2010). Comprehensive automated quality assurance of daily surface observations, National Climatic Data Center, 49, 1615-1633.

Kim, B.-J., Kim, J.-H., Cho, C.-H., and Sohn, K.-T. (2004). A Study on Homogeneity Test of Meteorological Observation Data and Filling of Missing Data, Journal of the Korean Data Analysis Society, 6, 293302.

Kim, C. and Suh, M.-S. (2008). Change-Point in the Recent (1976-2005) Precipitation over South Korea, Atmosphere, 18, 111-120.

Legates, D. R. and McCabe Jr., G. J. (1999). Evaluating the use of "goodness-of -fit" measures in hydrologic and hydroclimatic model evaluation, Water Resources Research, 35, 233-241.

Peterson, T. C. and Easterling, D. R. (1994). Creation of homogeneous composite climatological reference series, International Journal of Climatology, 14, 671-680.

Reeves, J., Chen, J., Wang, X. L., Lund, R. and Lu, Q. (2007). A review and comparison of change point detection techniques for climate data, American Meteorological Society, 46, 900-915.

Ryoo, S.-B., Kim, Y.-H., Kwon, T.-H. and Park, I.-S. (2006). Inhomogeneities in Korean Climate Data (I): Due to site relocation, Atmosphere, 16, 215-223.

Ryoo, S.-B. and Kim, Y.-H. (2007). Inhomogeneities in Korean Climate Data (II): Due to the changes of the Computing procedure of daily mean, Atmosphere, 17, 17-26.

Young, K. (1992). A three-way model for interpolating for monthly precipitation values, Monthly Weather Review, 120, 2561-2569. 